\title{
COMPETITIVE ABILITY OF WHEAT IN ASSOCIATION WITH BIOTYPES OF Raphanus raphanistrum L. RESISTANT AND SUSCEPTIBLE TO ALS-INHIBITOR HERBICIDES
}

\author{
Habilidade competitiva de trigo em convivência com biótipos de Raphanus raphanistrum L. \\ resistente e suscetível aos herbicidas inibidores de ALS
}

\author{
Leandro Oliveira da Costa ${ }^{1}$, Mauro Antônio Rizzardi ${ }^{2}$
}

\begin{abstract}
The occurrence of Raphanus raphanistrum ALS herbicide-resistant in wheat crops causes crop yield losses, which makes it necessary to understand the factors that influence the interference of this weed to develop safer management strategies. This study aimed to evaluate the competitive ability of wheat in coexistence with biotypes of $R$. raphanistrum that are resistant (R biotype) and susceptible (S biotypes) to ALS herbicides and to determine whether there are differences in the competitiveness of these biotypes. The experiments were conducted in a greenhouse using a completely randomized design with four replications. The treatments were placed in pots and arranged in replacement series for three experiments ( 1 - wheat with the R biotype; 2 - wheat with the $\mathrm{S}$ biotype; and 3 - the R biotype with the S biotype) at the following ratios: 100:0, 75:25, 50:50, 25:75, and 0:100. The competitiveness was analyzed through diagrams applied to replacement experiments and competitiveness indices, including the evaluation of the shoot dry matter of the plants (experiments 1, 2, and 3) and the leaf area (experiment 3). The R and S biotypes significantly decreased the shoot dry matter of the wheat cultivar and demonstrated superior competitive ability compared with the culture. The interspecific competition was more important for the wheat and for the $\mathrm{S}$ biotype. The competitiveness of the R biotype compared to the $\mathrm{S}$ biotype was similar, with synergism in the leaf area production, which indicates the predominant intraspecific competition exhibited by the R biotype.
\end{abstract}

Index terms: Resistance; competition; replacement series.

\begin{abstract}
RESUMO
A ocorrência de Raphanus raphanistrum resistente aos herbicidas ALS, em lavouras de trigo, ocasiona perdas de rendimento na cultura, sendo necessário conhecer os fatores que influenciam na interferência dessa planta daninha, para, assim, desenvolver estratégias de manejo com maior segurança. Objetivou-se avaliar a habilidade competitiva de trigo em convivência com biótipos de $R$. raphanistrum resistente (biótipo $\mathrm{R}$ ) e suscetível (biótipo $\mathrm{S}$ ) aos herbicidas ALS e se há diferenças de competitividade entre os biótipos. Os experimentos foram realizados em casa de vegetação, em delineamento inteiramente casualizado, com quatro repetições. Os tratamentos foram alojados em vasos e arranjados em série de substituição, em três experimentos: 1-trigo com biótipo R, 2- trigo com biótipo S e 3- biótipo R com biótipo S, nas proporções: 100:0, 75:25, 50:50, 25:75 e 0:100. A competitividade foi analisada por meio de diagramas aplicados a experimentos substitutivos e índices de competitividade, com avaliação da matéria seca da parte aérea das plantas (experimentos 1, 2 e 3) e área foliar (experimento 3). Os biótipos R e S diminuíram, significativamente, a matéria seca da parte aérea do cultivar de trigo e demonstraram habilidade competitiva superior à cultura. A competição interespecífica foi mais importante para o trigo e para o biótipo S. A competitividade do biótipo $\mathrm{R}$ em relação ao biótipo S foi semelhante, havendo sinergismo na produção de área foliar, predominando a competição intraespecífica no biótipo R.
\end{abstract}

Termos para indexação: Resistência; competição; série de substituição.

\section{INTRODUCTION}

In general, weed interference is a barrier to successful crop production (Afifi; Swanton, 2012). Crops are subject to interactions with other plant species with similar ecological niches. Such interactions with different plant species or populations from the same species are called interference. This interference may exhibit a positive, negative, or neutral nature depending on the species involved (Radosevich, 1987).
The ability of a species to interfere with another is related to several factors, including the plant species, the population density, the time of emergence of one species compared to another, and the plant characteristics (Radosevich, 1987; Bianchi; Fleck; Lamego, 2006). The effect of weeds on crops is not only due to their greater individual competitive ability but also to the total plant population (Vilà; Williamson; Lonsdale, 2004). In general, if two species are closer morphologically and physiologically, their growth factor requirements will be

\footnotetext{
1Universidade de Passo Fundo/UPF - Cx. P. 611 - 99052-900 - Passo Fundo - RS - Brasil - leandro.jari@gmail.com

2Universidade de Passo Fundo/UPF - Passo Fundo - RS - Brasil

Received in july 15, 2014 and approved in october 15, 2014
} 
more similar and their competition for limiting factors in the common environment will thus be more intense (Pitelli, 1987). There are three types of competition evident in plant associations: the competition among the plant organs, which is denoted intraplant competition, competition among plants of the same species, which is denoted intraspecific competition, and interference among different species, which is denoted interspecific competition (Park; Benjamin; Watkinson, 2002).

The methods that have been developed to study competition among plants allow the quantification of the losses caused by weeds and the competitiveness among species, which takes in to account the plant density, the species ratio, and the spatial arrangement at several levels and covers four main types: additive, systematic, response surface, and replacement series. The latter is the one that is most used in the study of the competition between plants because it allows the assessment of which species or biotypes are more competitive (Radosevich, 1987; Cousens, 1991). As the factors that influence the competition process are understood, the level of suppression and weed control can be determined with greater confidence, which would lead to the development of management strategies that result in reduced costs and higher yields (Fleck et al., 2006).

Raphanus raphanistrum is annual winter weed of the broad leaf species that are more competitive in winter cereals. The aggressiveness of this species has been attributed to its strong competitiveness capacity with crops, high prolificacy, longevity and seed bank dormancy, the presence of herbicide-resistant populations, and the ability to emerge and set seeds at various times of the year (Code; Donaldson, 1996).

Several researchers have studied the effects of the genus Raphanus on the growth and yield of wheat. Streibig et al. (1989) reported that the competitive ability of $R$. raphanistrum was 5- to 10 -fold greater than the competitive ability of Lolium rigidum in relation to wheat. Cousens et al. (2001), Eslami et al. (2006), and Rigoli et al. (2008) reported that $R$. raphanistrum was more competitive than wheat.

To recommend resistance prevention and management strategies in a rational manner, it is necessary to characterize the biological behavior of susceptible and resistant biotypes (Gill; Cousens; Allan, 1996). High concentrations of valine and leucine have been observed in the leaves of the biotypes Lactuca serriola resistant to ALS inhibitors herbicides when was compared to susceptible biotypes (Eberlein et al., 1999). These amino acids are responsible for DNA synthesis, which would allow faster cell division and growth under milder temperatures in the resistant biotypes compared to the susceptible biotypes (Dyer; Chee; Fay; 1993). The consequences of this ecological fitness include a faster emergence speed of the resistant biotype, which would in turn allow a faster occupation of the ecological niche compared to the susceptible biotype and therefore a competitive advantage.

As a result, it has been hypothesized that $R$. raphanistrum has a superior competitive ability than wheat and that there may be differences in the competitiveness among biotypes of $R$. raphanistrum that are resistant and susceptible to ALS-inhibitor herbicides. Thus, this study aimed to investigate the competitive ability of wheat in coexistence with biotypes of $R$. raphanistrum that are susceptible and resistant to ALS-inhibitor herbicides and to determine whether there are differences in the competitiveness between the different biotypes.

\section{MATERIAL AND METHODS}

Seeds were collected from populations of Raphanus raphanistrum $\mathrm{L}$. with suspected resistance to the ALS-inhibitor herbicides in areas of control failure, in northern Paraná. After confirming resistance to ALS inhibitors (Costa; Rizzardi, 2014), the seeds of these plants constituted the resistant population of Raphanus raphanistrum ( $\mathrm{R}$ biotype). To obtain the susceptible population (S biotype), seeds were collected from plants of $R$. raphanistrum in northern Paraná, near the collection site of the resistant population, where there was no history of application of ALS inhibitors herbicides.

Three experiments were conducted in a greenhouse. The experimental units consisted of plastic pots that were $30 \mathrm{~cm}$ in diameter and $26 \mathrm{~cm}$ in height with a volume capacity of $11.5 \mathrm{~L}$ and a surface area of $0.07 \mathrm{~m}^{2}$. The pots were filled with a mixture of commercial substrate of type Turfa Fertil ${ }^{\circledR}$ in addition to soil derived from the experimental area, which was classified as typical Dystrophic Red Latosol. The wheat cultivar Quartzo ${ }^{\circledR}$ was used for the experiments. The population density was adjusted according to the "Law of Final Constant Yield". The population was then thinned to eight plants per pot, which is equivalent to 114 plants $\mathrm{m}^{-2}$, to achieve a constant dry matter (DM) yield. The following treatments were conducted in replacement series and included a combination of five ratios: experiment 1 (EXP1) - wheat with R biotype; experiment 2 (EXP2) - wheat with $\mathrm{S}$ biotype; and experiment 3 (EXP3) - R biotype with $\mathrm{S}$ biotype. The combined ratios of wheat and $\mathrm{R}$ biotype were 8 and 0,6 and 2, 4 and 4, 2 and 4, and 0 and 8 , which 
are equivalent to $100,75,50,25$, and $0 \%$, respectively, of wheat plants and the opposite for the R biotype. This ratio was maintained in all experiments. The treatments were arranged in a completely randomized design with four replications, and the position of the pots was changed periodically to ensure homogeneous experimental conditions.

The seeds from wheat and the $\mathrm{R}$ and $\mathrm{S}$ biotypes were germinated in Styrofoam trays and filled with Turfa Fertil ${ }^{\circledR}$ substrate. In preliminary tests, the emergence speed of the wheat and biotypes seeds was determined to ensure that the emergence of these coincided. One week after germination, the seedlings of wheat and $\mathrm{R}$ and $\mathrm{S}$ biotypes were transplanted to the experimental units. This process eliminates the effects of different germination speeds on the competitive process, which could mask the result. The experimental units remained under intermittent irrigation throughout the duration of the experiment.

Sixty days after emergence (DAE), all of the plants were harvested (cut close to the ground) for the evaluation of the dry matter yield. The wheat was in the elongation stage, whereas the R biotype was in the fruiting stage, and the $\mathrm{S}$ biotype was in the flowering stage. After harvesting, the plants were packaged in paper bags, labeled, and maintained in an incubator at $65^{\circ} \mathrm{C}$ for $72 \mathrm{~h}$. The shoot dry matter (SDM) was determined with a precision scale. In EXP3, the leaf area $\left(\mathrm{LA}\right.$, in $\left.\mathrm{cm}^{2}\right)$ of the plants was also evaluated with the aid of a LI-COR leaf area meter (model LI-3100C).

For the data analysis, graphical and conventional analysis methods were used for the replacement experiments (Cousens, 1991). This method consists of the construction of diagrams based on the relative yield (RY) and the total relative yield (TRY) at the ratios of 0,25 , 50,75 , and $100 \%$ of the crop and the weed, the resistant weed, or the susceptible weed.

The RY was calculated by dividing the mean of the mixture by the monoculture mean, and the mean per plant of each species in each experimental unit was included in the calculation. The TRY represents the sum of the RY values of the competitors at the respective plant ratios (Hoffman; Buhler, 2002).

The formulas for calculating the relative and total productivities are given below according to Hoffman and Buhler (2002): $\mathrm{RYa}=(\mathrm{p})($ Amix/Amon $) ; \mathrm{RYb}=(1-\mathrm{p})$ $(\mathrm{Bmix} / \mathrm{Bmon}) ; \mathrm{TRY}=\mathrm{RYa}+\mathrm{RYb}$, in which $\mathrm{RYa}=$ relative productivity of the species "a" (wheat - EXP1 and EXP2 or biotypes - EXP3); RYb = relative productivity of the species b (Raphanus raphanistrum); $\mathrm{p}=$ proportion of " $\mathrm{a}$ " in $\%$ divided by $100 ;$ Amix = value of the variable to be analyzed ( e.g. dry mass) of "a" mixed; Amon = value of the variable to be analyzed of "a" in monoculture; Bmix = value of the variable to be analyzed of " $b$ " in mixed; Bmon $=$ value of the variable to be considered of a " $b$ " in monoculture, and TRY = total relative productivity.

If the RY results in a straight line, there is no competition effect between the species, which indicates that their competitive abilities are equivalent. In contrast, if the RY results in a convex line, there is benefit to one or both species, and, if the RY results in a concave line, there is a loss to one or both of the species. If the TRY equals 1 (straight), there is competition for the same resources, whereas, if TRY is greater than 1 (convex), there is no competition because the demand does not exceed the resources or because the species have different ecological niches, and, if TRY is less than 1 (concave), there is antagonism that results in mutual loss to the species involved (Hoffman; Buhler, 2002).

The relative competitive index (RCI), the relative clustering coefficient $(\mathrm{K})$, and the relative aggression coefficient (A) were calculated at the following ratios: 50\% wheat with the R biotype (EXP1), 50\% wheat with the S biotype (EXP2), and $50 \% \mathrm{R}$ biotype with the $\mathrm{S}$ biotype (EXP3). The RCI represents the comparative growth of species "a" compared to species "b", whereas $\mathrm{K}$ indicates the relative dominance of one species over another, and A demonstrates which species is more competitive. Through the interpretation of these values, it is possible to measure the competitiveness degree between species (Cousens, 1991).

The formulas of these indices are given below according to Hoffman and Buller (2002): RCI $=((1-p) / p)$ $(\mathrm{RYa} / \mathrm{RYb}) ; \mathrm{Ka}=((1-\mathrm{p}) / \mathrm{p})(\mathrm{RYa} /(1-\mathrm{RYa})) ; \mathrm{Kb}=((1$ - p)/p) $(R Y b /(1-R Y b)) ; a=(R Y a / 2 p)-(R Y b /(2(1-p))$. Species "a" is more competitive than species " $b$ " if $\mathrm{RCI}>1, \mathrm{Ka}>\mathrm{Kb}$, and $\mathrm{A}>0$, whereas species " $\mathrm{b}$ " is more competitive if $\mathrm{RCI}<1, \mathrm{Ka}<\mathrm{Kb}$ and $\mathrm{A}<0$.

To perform a statistical analysis of the relative yields, the differences in the RY values (RYD) obtained at the ratios of 25,50 , and $75 \%$ of the plants in relation to the values belonging to the hypothetical lines at their respective ratios $(0.25,0.50$, and 0.75$)$ were calculated (Fleck et al., 2008). A t-test ( $\mathrm{p} \leq 0.05)$ was used to test the relative differences in the RYD, TRY, RCI, K, and A indices compared with the hypothetical lines using the SAS statistical software (Statistical Analysis System, version 8.0).

The null hypothesis used to test the differences between RYD and A assumed that the means were equal to zero $\left(\mathrm{H}_{0}=0\right)$. In contrast, the corresponding null hypothesis for the differences between TRY and RCI assumed that the means were equal to unity $\left(\mathrm{H}_{0}=1\right)$, and 
the null hypothesis for the differences between the $\mathrm{K}$ index assumed that the means of the differences between $\mathrm{Ka}$ and $\mathrm{Kb}$ were equal to zero $\left(\mathrm{H}_{0}=(\mathrm{Ka}-\mathrm{Kb})=0\right)$. The variables SDM and LA were expressed as the mean values per plant and subjected to analysis of variance. When significant, the means were compared by Dunnett's test $(p \leq 0.05)$ considering the monocultures as witnesses.

\section{RESULTS AND DISCUSSION}

The graphical analysis of the results of the relative yield (RY) of the shoot dry matter (SDM) demonstrated that the $\mathrm{R}$ biotype was more competitive than wheat. Compared to the hypothetical lines (Figure 1a), the RY of the R biotype was represented by a convex line and that of wheat was represented by a concave line, particularly at the ratios of 50:50 and 25:75 for the wheat and 75:25 and 50:50 for the $\mathrm{R}$ biotype, for which the difference was significant (Table 1). Note that the wheat plants were affected when the $R$ biotype had equal or higher plant density. In addition, the weed species, at lower or equal densities to that of wheat, showed an increased relative yield, which characterizes it as an aggressive species towards the crop.

The total relative yield (TRY) observed was close to the expected values (Figure 1a), and no significant difference were obtained with respect to the hypothetical line (Table 1). This finding indicates the existence of competition for the same resource(s), i.e., the wheat is affected by the weed; however, the final yield did not differ from the expected productivity (Radosevich, 1987).

The competitiveness indices show that the $\mathrm{R}$ biotype was more competitive than wheat because RCI
$<1, \mathrm{~K}_{\mathrm{T}}<\mathrm{K}_{\mathrm{S}}$, and $\mathrm{A}<0$ and all of these were significant (Table 2). These results indicate that the weed was more competitive, dominant, and more aggressive than the wheat plant. The response of wheat to the R biotype interference at different plant ratios showed a significant difference only in the SDM yield of the wheat compared to the monoculture, when the crop was found at a lesser ratio than the weed (Table 3). This result indicates that there was interspecific competition that resulted in crop losses. This statement is in accordance with the findings obtained by Wandscheer, Rizzardi and Reichert (2013), who observed interspecific competition between corn and Eleusine indica, in which the corn SDM yield was hindered if the weed was found at a higher ratio.

Rigoli et al. (2008), who worked with wheat and $R$. raphanistrum in a replacement series experiment, observed that the weed species was more competitive than the crop and that these competed for the same resources. In contrast, Yamauti, Alves and Carvalho (2011) found that Triticum turgidosecale was more efficient at capturing resources from the environment than Raphanus raphanistrum, which indicates that this crop was a better competitor than the weed.

The graphical analysis of the results related to the RY of the SDM showed that the S biotype was more competitive than wheat. Compared with the hypothetical lines, the RY of the weed was represented by a convex line, and the crop was represented by a concave line (Figure $1 b)$. With respect to the RY of wheat and the S biotype, the differences were significant at all ratios. The analysis of the TRY values showed that these were significant at the ratios 75:25 and 50:50 (Table 1).
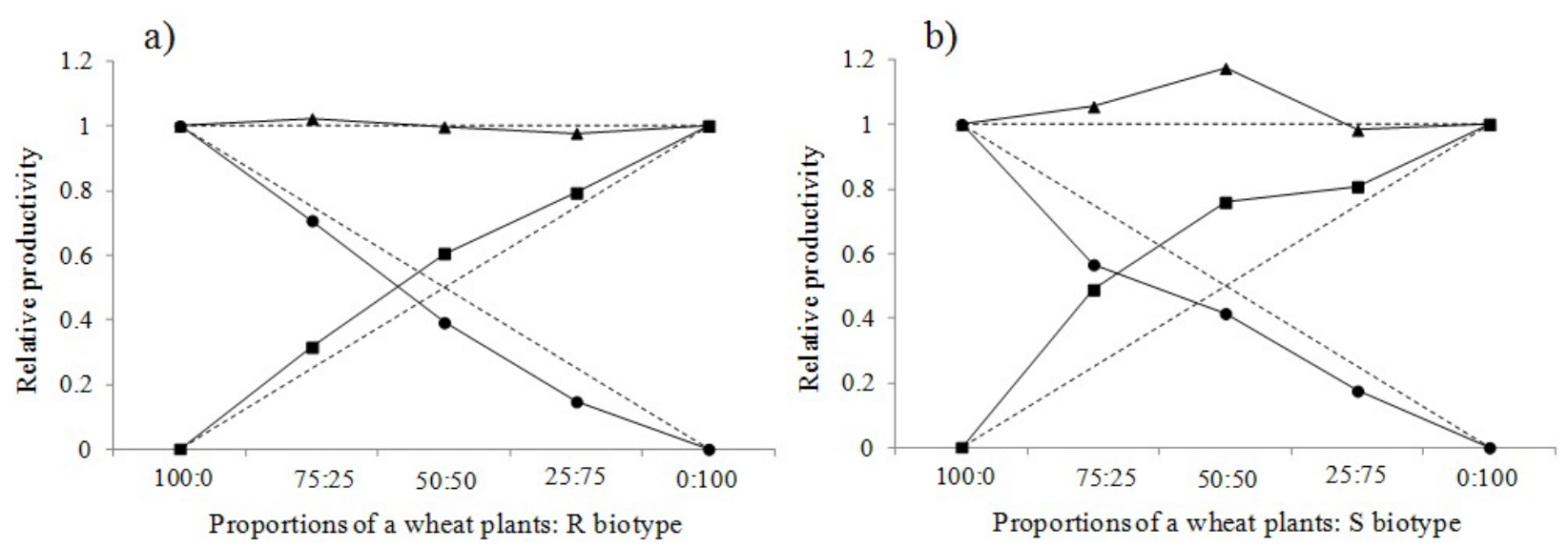

Figure 1: Relative productivity (RY) and total productivity (TRY) for dry mass of shoots of wheat crop and R biotype (a) and S biotype (b) of Raphanus raphanistrum, depending on the proportion of plants. (•) Wheat cultivar RY (घ) R biotype and $\mathrm{S}$ biotype RY and ( $\mathbf{\Delta}) \mathrm{TRY}$. Dashed lines represent the hypothetical relative productivity when there is no interference of one species over another. 
Table 1: Relative differences in productivity (RYD), for the variables shoot dry mass (SDM) and leaf area (LA) and total relative productivity (TRY) in proportion of 75/25; 50/50 and 25/75 of wheat crop associated with R or $\mathrm{S}$ biotypes of Raphanus raphanistrum or $\mathrm{R}$ biotype and $\mathrm{S}$ biotype.

\begin{tabular}{|c|c|c|c|}
\hline \multicolumn{4}{|c|}{ Plant proportion (wheat / R biotype) EXP1 } \\
\hline SDM & $75 / 25$ & $50 / 50$ & $25 / 75$ \\
\hline RYD wheat & $-0.04( \pm 0.03)^{\mathrm{ns}}$ & $-0.11( \pm 0.02)^{*}$ & $-0.10( \pm 0.01)^{*}$ \\
\hline RYD R biotype & $0.07( \pm 0.01)^{*}$ & $0.11( \pm 0.02)^{*}$ & $0.08( \pm 0.05)^{\mathrm{ns}}$ \\
\hline TRY & $1.02( \pm 0.03)^{\mathrm{ns}}$ & $1.00( \pm 0.03)^{\mathrm{ns}}$ & $0.98( \pm 0.04)^{\mathrm{ns}}$ \\
\hline \multicolumn{4}{|c|}{ Plant proportion (wheat / S biotype) EXP2 } \\
\hline SDM & $75 / 25$ & $50 / 50$ & $25 / 75$ \\
\hline RYD wheat & $-0.18( \pm 0.02)^{*}$ & $-0.09( \pm 0.01)^{*}$ & $-0.07( \pm 0.01)^{*}$ \\
\hline RYD S biotype & $0.24( \pm 0.01)^{*}$ & $0.26( \pm 0.02)^{*}$ & $0.06( \pm 0.03)^{*}$ \\
\hline TRY & $1.05( \pm 0.01)^{*}$ & $1.17( \pm 0.01)^{*}$ & $0.98( \pm 0.06)^{\mathrm{ns}}$ \\
\hline \multicolumn{4}{|c|}{ Plant proportion (R biotype / S biotype) EXP3 } \\
\hline SDM & $75 / 25$ & $50 / 50$ & $25 / 75$ \\
\hline RYD R biotype & $-0.15( \pm 0.12)^{\mathrm{ns}}$ & $-0.04( \pm 0.07)^{\mathrm{ns}}$ & $0.03( \pm 0.06)^{\mathrm{ns}}$ \\
\hline RYD S biotype & $0.04( \pm 0.04)^{\mathrm{ns}}$ & $0.00( \pm 0.09)^{\mathrm{ns}}$ & $0.12( \pm 0.13)^{\mathrm{ns}}$ \\
\hline TRY & $1.19( \pm 0.13)^{\mathrm{ns}}$ & $1.04( \pm 0.06)^{\mathrm{ns}}$ & $1.15( \pm 0.15)^{\mathrm{ns}}$ \\
\hline LA & $75 / 25$ & $50 / 50$ & $25 / 75$ \\
\hline RYD R biotype & $0.14( \pm 0.02)^{*}$ & $0.41( \pm 0.12)^{*}$ & $0.56( \pm 0.11)^{*}$ \\
\hline RYD S biotype & $0.83( \pm 0.09)^{*}$ & $0.69( \pm 0.19)^{*}$ & $0.44( \pm 0.11)^{*}$ \\
\hline TRY & $1.97( \pm 0.11)^{*}$ & $2.10( \pm 0.28)^{*}$ & $1.90( \pm 0.25)^{*}$ \\
\hline
\end{tabular}

${ }^{n s}$ Not significant $*$ Significant by t test $(\mathrm{P}(\mathrm{p} \leq 0.05)$. Values in parenthesis represent the standard error of the average.

Table 2: Competitiveness indices (RCI) of wheat crop associated with R or S biotypes of Raphanus raphanistrum or $\mathrm{R}$ biotype and $\mathrm{S}$ biotype, expressed by relative competitiveness clustering coefficients $(\mathrm{K})$ and aggressiveness $(\mathrm{A})$.

\begin{tabular}{|c|c|c|c|}
\hline \multicolumn{4}{|c|}{$\mathrm{SDM}^{1 /}$ (wheat $\mathrm{x}$ R biotype) EXP1 } \\
\hline $\mathrm{RCI}$ & $\mathrm{K}_{\mathrm{T}}=$ wheat & $\mathrm{K}_{\mathrm{S}}=\mathrm{R}$ biotype & A \\
\hline $0.65( \pm 0.04)^{*}$ & $0.65( \pm 0.05)^{*}$ & $1.56( \pm 0.15)^{*}$ & $-0.21( \pm 0.03)^{*}$ \\
\hline \multicolumn{4}{|c|}{ SDM (wheat x S biotype) EXP2 } \\
\hline $\mathrm{RCI}$ & $\mathrm{K}_{\mathrm{T}}=$ wheat & $\mathrm{K}_{\mathrm{S}}=\mathrm{S}$ biotype & A \\
\hline $0.55( \pm 0.02)^{*}$ & $0.71( \pm 0.02)^{*}$ & $3.21( \pm 0.30)^{*}$ & $-0.34( \pm 0.03)^{*}$ \\
\hline \multicolumn{4}{|c|}{ SDM (R biotype $\mathrm{x} S$ biotype) EXP3 } \\
\hline $\mathrm{RCI}$ & $\mathrm{K}_{\mathrm{R}}=\mathrm{R}$ biotype & $\mathrm{K}_{\mathrm{S}}=\mathrm{S}$ biotype & $\mathrm{A}$ \\
\hline $1.25( \pm 0.30)^{\mathrm{ns}}$ & $1.31( \pm 0.31)^{\mathrm{ns}}$ & $1.28( \pm 0.54)^{\mathrm{ns}}$ & $0.07( \pm 0.14)^{\mathrm{ns}}$ \\
\hline \multicolumn{4}{|c|}{ LA 2 (R biotype $\mathrm{x}$ S biotype) EXP3 } \\
\hline $0.80( \pm 0.12)^{\mathrm{ns}}$ & $16.25( \pm 16.15)^{\mathrm{ns}}$ & $4.22( \pm 5.24)^{\mathrm{ns}}$ & $-0.28( \pm 0.16)^{\mathrm{ns}}$ \\
\hline
\end{tabular}

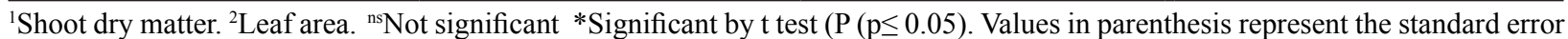
of the average. 
At these ratios, the TRY was greater than 1 (and was thus characterized by a convex line with respect to the hypothetical line), which indicates that there was no competition between the species. This finding was obtained because the environmental resources exceeded the demand of both species or because the species have different demands for environmental resources (Rigoli et al., 2008). This behavior, especially at the ratio in which the specie are equivalent, demonstrated that the weed is more aggressive than the crop and thus contributes more than expected to the TRY and the SDM yield (Radosevich, 1987).

There were significant differences in all of the competitiveness indices (Table 2). The $\mathrm{S}$ biotype has been found to be more competitive and dominant and is more aggressive compared to wheat, as reflected by the following results: $\mathrm{RCI}<1, \mathrm{~K}_{\mathrm{T}}<\mathrm{K}_{\mathrm{S}}$, and $\mathrm{A}<0$. Through the joint interpretation of these values, it can be concluded that the $\mathrm{S}$ biotype exhibits greater competitive ability compared to wheat (Cousens, 1991). These results are in agreement with the competitiveness indices of wheat in with respect to the $\mathrm{R}$ biotype, which demonstrates that $\mathrm{R}$ and $\mathrm{S}$ biotypes exert similar competitive ability when subjected to competition with wheat.

In competition assays between soybean plants and Raphanus sativus, it was observed that the weed has superior competitiveness ability than the crop (Bianchi et al., 2006). Results in which $R$. sativus was more competitive than soybean have also been reported by Fleck et al. (2006) and Bianchi et al. (2011). Galon et al. (2011) found that Lolium multiflorum has a higher competitive ability compared to Hordeum vulgare. Estorninos Juniorr, Gealy and Talbert (2002) observed that rice cultivars have lower or similar competitiveness compared to red rice biotypes.

The comparison of the crop's response to the competitor's interference revealed a significant decrease in the SDM yield when the wheat was found at a lower ratio (Table 3). This result suggests that there was interspecific competition. In the $\mathrm{S}$ biotype, the interspecific competition also had a significant effect, with a decrease in the SDM when the weed was found at a smaller or equal amount compared with the crop. These results corroborate those reported by Eslami et al. (2006), who observed that, when the wheat density was increased from 100 to $400 \mathrm{~m}^{-2}$, there was a decrease in the $R$. raphanistrum dry mass to less than $50 \%$. Cousens et al. (2001) cultured wheat and $R$. raphanistrum in monocultures and mixtures to study the competition between both species until wheat anthesis. These researchers concluded that the presence of wheat increased the height and specific leaf area of $R$. raphanistrum, but reduced the dry mass and the number of seeds of the weed. Agostinetto et al. (2008) discovered that Echinochloa spp. was more competitive than irrigated rice cultivars.

Table 3: Wheat response to interference with $\mathrm{R}$ biotype or $\mathrm{S}$ biotype of Raphanus raphanistrum or $\mathrm{R}$ biotype and $\mathrm{S}$ biotype at 60 days after emergence.

\begin{tabular}{|c|c|c|c|c|c|c|}
\hline \multirow{2}{*}{$\mathrm{SDM}^{1 /}$} & \multicolumn{6}{|c|}{ Plant proportion (wheat $x$ R biotype) EXP 1} \\
\hline & $100 / 0(\mathrm{~T})$ & $75 / 25$ & $50 / 50$ & $25 / 75$ & $0 / 100(\mathrm{~T})$ & $\mathrm{CV}(\%)$ \\
\hline Wheat & 5.79 & 5.54 & 4.35 & $3.33 *$ & - & 21.9 \\
\hline $\mathrm{R}$ biotype & - & 8.15 & 8.99 & 10.39 & 10.23 & 19.2 \\
\hline $\mathrm{SDM}^{1 /}$ & \multicolumn{6}{|c|}{ (wheat $x \mathrm{~S}$ biotype) EXP 2} \\
\hline Wheat & 6.18 & 4.71 & 5.07 & $4.40 *$ & - & 15.7 \\
\hline $\mathrm{S}$ biotype & - & $7.18 *$ & $7.64 *$ & 10.89 & 13.79 & 22.5 \\
\hline $\mathrm{SDM}^{1 /}$ & \multicolumn{6}{|c|}{ (R biotype $\mathrm{x} S$ biotype) EXP 3} \\
\hline $\mathrm{R}$ biotype & 4.99 & 6.02 & 5.37 & 5.50 & - & 29.9 \\
\hline S biotype & - & 5.61 & 6.51 & 5.59 & 6.42 & 28.0 \\
\hline $\mathrm{LA}^{2} /$ & \multicolumn{6}{|c|}{ (R biotype $\mathrm{x} S$ biotype) EXP 3} \\
\hline $\mathrm{R}$ biotype & 307 & 365 & 559 & $866^{*}$ & - & 41.3 \\
\hline S biotype & - & $286^{*}$ & $456^{*}$ & $683^{*}$ & 1240 & 23.6 \\
\hline
\end{tabular}

${ }^{1}$ Shoot dry matter. ${ }^{2}$ Leaf area. *Average differs from control (T) by Dunnett's test $(\mathrm{p} \leq 0.05)$. 
In contrast, there are reports in which the crop has greater competitive ability compared to the weed. Passini, Christoffoleti and Yada (2003) observed that intraspecific competition was more important in Phaseolus vulgaris than in Brachiaria plantaginea because the competitiveness of the crop was superior to that of the weed. Cultured sorghum showed superior competitive ability compared with Sorghum halepense (Hoffman; Buhler, 2002). Phaseolus vulgaris was more competitive than five species of Amaranthus (Carvalho; Christoffoleti, 2008).

The graphical analysis of the RY and TRY results related to the SDM production in the $\mathrm{R}$ and $\mathrm{S}$ biotypes showed similar behavior: the values obtained did not differ significantly from the expected values at all ratios (Figure 2a and table 1). This result suggests that the SDM yield of the $\mathrm{R}$ and $\mathrm{S}$ biotypes were not negatively affected by the association and that both biotypes were able to grow as monocultures with no competition between them. At all plant ratios, the TRY values were greater than 1, and competition was avoided by the fact that the supply of resources exceeded the demand. However, because there was no significance difference in the TRY, the R and $\mathrm{S}$ biotypes likely competed similarly for the environmental resources.

The graphical analysis of the leaf area (LA) shows that both biotypes had gains above the expected values (Figure 2b). The RY and TRY of the biotypes are represented by convex lines, which suggests mutual benefits between them. The RY and TRY deviations show significant differences at all plant ratios (Table 1).
The synergism observed between the $\mathrm{R}$ and $\mathrm{S}$ biotypes can be related to the fact that the amount of available resources was sufficient for both species or that the plant density was lower than that tolerated by the environment, which resulted in the absence of competition. This finding was confirmed by Rizzardi et al. (2004), who analyzed the association between soybean plants and Euphorbia heterophylla and Ipomoea ramosissima and observed a mutual benefit among the species; in fact, if found in mixtures, these species produced more biomass than that obtained in monocultures of these species.

The results obtained from the competitiveness indices demonstrate that there was no significant dominance between the $\mathrm{R}$ and $\mathrm{S}$ biotypes with respect to the SDM and LA (Table 2). This finding shows that the biotypes have the same characteristics with regards to ecological adaptability and do not compete with one another under the experimental conditions studied. It is likely that these species have the same competitiveness if found in coexistence with each other and that the numerical dominance of one biotype over the other would be caused solely by the herbicide selection pressure (Christoffoleti, 2001).

The verification the response of the $\mathrm{R}$ biotype to the $S$ biotype interference revealed that there was no significant difference in the SDM, which indicated the absence of competition between the species. In contrast, there was significant difference in the LA when the R biotype was present at a smaller ratio (Table 3 ). The $\mathrm{R}$ biotype prefers to coexist with the $\mathrm{S}$ biotype, as demonstrated by the fact a)

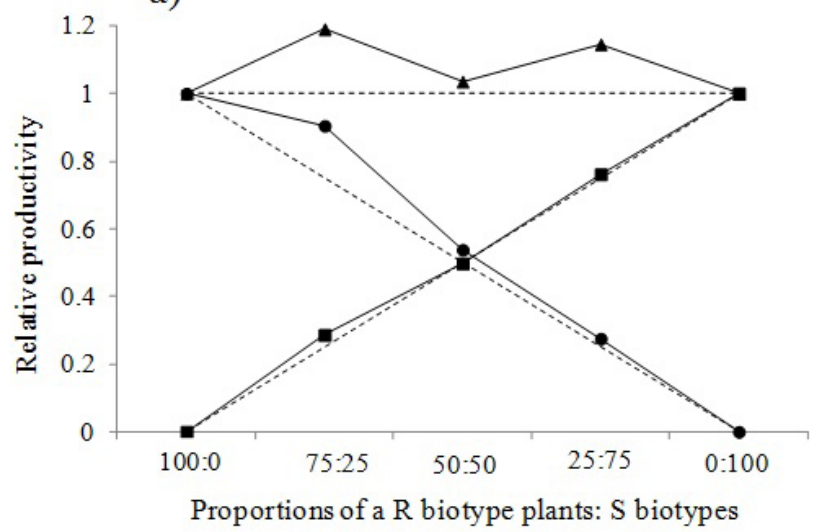

b)

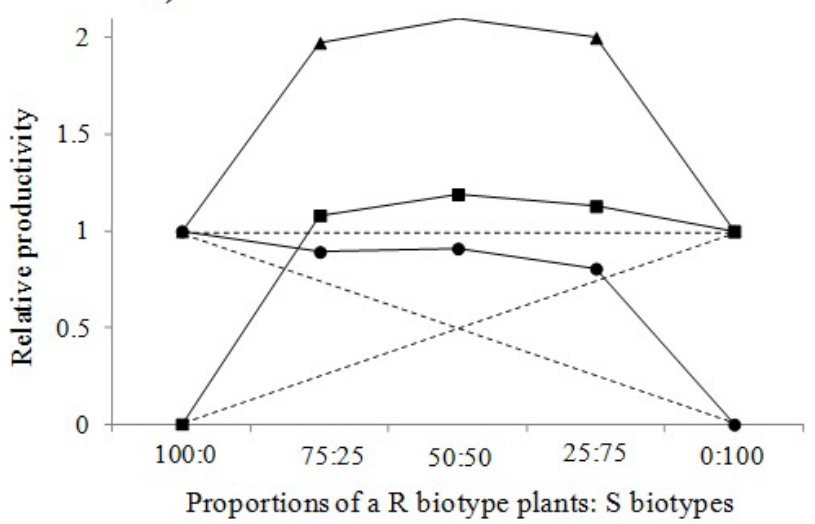

Figure 2: Relative productivity (RY) and total productivity (TRY) for dry mass of shoots of R biotype and S biotype (a); for leaf area (LA) of shoots of R biotype and S biotype (b) of Raphanus raphanistrum, depending on the proportion of

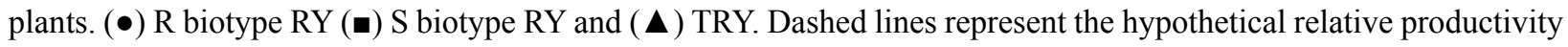
when there is no interference of one species over another. 
that the LA yield was higher compared to that observed in monoculture conditions, which indicates intraspecific competition. The opposite occurs with the S biotype, which is less efficient in competing for the environmental resources compared to the $\mathrm{R}$ biotype. This may be related to the fact that the $\mathrm{R}$ biotype reached the flowering stage two weeks prior to shoot harvest, whereas the $\mathrm{S}$ biotype was in the flowering stage. Thus, the $\mathrm{R}$ biotype required higher amounts of nutrients in the flowering stage, which resulted in intraspecific competition. In addition, the $\mathrm{S}$ biotype was not in the flowering stage at the same time as the R biotype; thus, the amount of nutrient spent was lower, which resulted in competition when in association with the R biotype.

The competitive ability of Digitaria ciliaris biotypes that are resistant and susceptible to ACCase inhibitors is similar, and both species have the same ecological adaptability but lower competitive ability compared with soybean (Ovejero et al., 2007). There were no significant differences in the competitive ability between resistant and susceptible biotypes of Bidens subalternans (Lamego; Vidal; Burgos, 2011). Bidens pilosa biotypes susceptible to ALS inhibitors exhibited higher dry matter accumulation in the early growth stages compared to the resistant biotypes; however, at the end of the cycle, this characteristic became similar, with no differences between them (Christoffoleti, 2001). Dal Magro et al. (2011) also observed equivalent competitive abilities between Cyperus difformis biotypes that are resistant and susceptible to ALS inhibitors. In contrast, Ferreira et al. (2008) found that Lolium multiflorum biotypes that are susceptible to glyphosate are more competitive than the biotype that is resistant to this herbicide.

Thus, the results of this study show that the $\mathrm{R}$ and $\mathrm{S}$ biotypes have superior competitive ability compared to the wheat cultivar Quartzo ${ }^{\circledR}$ and that, in general, there is no difference in competitive ability between the biotypes that are resistant and susceptible to ALS inhibitor herbicides under replacement series experimental conditions. Thus, the only manner in which the $R$. raphanistrum resistant population can obtain an advantage in the field with respect to the susceptible population is through the selection imposed by herbicides composed of ALS inhibitors.

\section{CONCLUSIONS}

Raphanus raphanistrum biotypes resistant and susceptible to the ALS inhibitors, have superior competitive ability to cultivate Quartzo ${ }^{\circledR}$ wheat.
The competitiveness of $R$. raphanistrum susceptible and resistant to ALS inhibitors is similar, with no dominance of a biotype over the other.

\section{REFERENCES}

AFIFI, M.; SWANTON, C. Early physiological mechanisms of weed competition. Weed Science. 60(4):542-551, 2012.

AGOSTINETTO, D. et al. Competitividade relativa entre cultivares de arroz irrigado e biótipo de capimarroz (Echinochloa spp.). Planta Daninha. 26(4):757766, 2008.

BIANCHI, M.A.; FLECK, N.G.; LAMEGO, F.P. Proporção entre plantas de soja e plantas competidoras e as relações de interferência mútua. Ciência Rural. 36(5):1380-1387, 2006.

BIANCHI, M.A. et al. Interferência de Raphanus sativus na produtividade de cultivares de soja. Planta Daninha. 29(4):783-792, 2011.

CARVALHO, S.J.P.; CHRISTOFFOLETI, P.J. Competition of Amaranthus species with dry bean plants. Scientia Agricola. 65(3):239-245, 2008.

CHRISTOFFOLETI, P.J. Análise comparativa do crescimento de biótipos de picão-preto (Bidens pilosa) resistente e suscetível aos herbicidas inibidores da ALS. Planta Daninha. 19(1):75-83, 2001.

CODE, G.R.; DONALDSON, W. Effect of cultivation, sowing methods and herbicides on wild radish populations in wheat crops. Australian Journal of Experimental Agriculture. 36(34):437442, 1996.

COSTA, L.O.; RIZZARDI, M.A. Resistance of Raphanus raphanistrum to the herbicide MetsulfuronMethyl. Planta Daninha. 32(1):181-187, 2014.

COUSENS, R. Aspects of the design and interpretation of competition (interference) experiments. Weed

Technology. 5(3):664-673, 1991.

COUSENS, R. et al. Early growth and development of wild radish (Raphanus raphanistrum $\mathrm{L}$.) in relation to wheat. Australian Journal of Agricultural Research. 52(7):755-769, 2001. 
DAL MAGRO, T. et al. Habilidade competitiva entre biótipos de Cyperus difformis L. resistente ou suscetível a herbicidas inibidores de ALS e destes com arroz irrigado. Bragantia. 70(2):294-301, 2011.

DYER, W.E.; CHEE, P.W.; FAY, P.K. Rapid germination of sulfonylurea-resistant Kochia scoparia L. accessions is associated with elevated seed levels of branched chain amino acids. Weed Science. 41(1):18-22, 1993.

EBERLEIN, C.V. et al. Physiological consequences of mutation for ALS-inhibitor resistance. Weed Science. 47(4):383-392, 1999.

ESLAMI, S.V. et al. Wild radish (Raphanus raphanistrum) interference in wheat. Weed Science. 54(4):749-756, 2006.

ESTORNINOS JUNIOR., L.E.; GEALY, D.R.; TALBERT, R.E. Growth response of rice (Oryza sativa) and red rice (O. sativa) in a replacement series study. Weed Technology. 16(2):401-406, 2002.

FERREIRA, E.A. et al. Potencial competitivo de biótipos de azevém (Lolium multiflorum). Planta Daninha. 26(2):261-269, 2008.

FLECK, N. G. et al. Competitividade relativa entre cultivares de arroz irrigado e biótipo de arroz-vermelho. Planta Daninha. 26(1):101-111, 2008.

FLECK, N. G. et al. Interferência de Raphanus sativus sobre cultivares de soja durante a fase vegetativa de desenvolvimento da cultura. Planta Daninha. 24(3):425-434, 2006.

GALON, L. et al. Habilidade competitiva de cultivares de cevada convivendo com azevém. Planta Daninha. 29(4):771-781, 2011.

GILL, G.S.; COUSENS, R.D; ALLAN, M.R. Germination, growth, and development of herbicide resistant and susceptible populations of rigid ryegrass (Lolium rigidum). Weed Science. 44(2):252-256, 1996.

HOFFMAN, M.L.; BUHLER, D.D. Utilizing Sorghum as a functional model of crop-weed competition. I. Establishing a competitive hierarchy. Weed Science. 50(4):466-472, 2002.
LAMEGO, F.P.; VIDAL, R.A.; BURGOS, N.R.. Competitiveness of ALS inhibitors resistant and susceptible biotypes of Greater Beggarticks (Bidens subalternans). Planta Daninha. 29(2):457-464, 2011.

OVEJERO, R.F.L. et al. Crescimento e competitividade de biótipos de capim-colchão resistente e suscetível aos herbicidas inibidores da acetil coenzima A carboxilase. Pesquisa Agropecuária Brasileira. 42(1):1-8, 2007.

PARK, S.E.; BENJAMIN, L.R.; WATKINSON, A.R. Comparing biological productivity in cropping systems: a competition approach. Journal of Applied Ecology. 39(3):416-426, 2002.

PASSINI, T.; CHRISTOFFOLETI, P.J.; YADA, I.F.U. Competitivity of the common-bean plant relative to the weed alexandergrass (Brachiaria plantaginea (Link) Hitch.). Scientia Agricola. 60(2):259-268, 2003.

PITELLI, R. A. Competição e controle de plantas daninhas em áreas agrícolas. Série Técnica IPEF. 4(12):1-24, 1987.

RADOSEVICH, S.R. Methods to study interactions among crops and weeds. Weed Technology. 1(3):190198, 1987.

RIGOLI, R.P. et al. Habilidade competitiva relativa do trigo (Triticum aestivum) em convivência com azevém (Lolium multiflorum) ou nabo (Raphanus raphanistrum). Planta Daninha. 26(1):93-100, 2008.

RIZZARDI, M.A. et al. Interferência de populações de Euphorbia heterophylla e Ipomoea ramosissima isoladas ou em misturas sobre a cultura de soja. Planta Daninha. 22(1):29-34, 2004.

STREIBIG, J.C. et al. Estimation of thresholds for weed control in Australian cereals. Weed Research. 29(2):117-126, 1989.

VILÀ, M.; WILLIAMSON, M.; LONSDALE, M. Competition experiments on alien weeds with crops: lessons for measuring plant invasion impact? Biological Invasions. 6(1):59-69, 2004. 
WANDSCHEER, A.C.D.; RIZZARDI, M.A.; REICHERT, M. Competitive ability of corn in coexistence with goosegrass. Planta Daninha. 31(2):281-289, 2013.
YAMAUTI, M.S.; ALVES, P.L.C.A.; CARVALHO, L.B. Interações competitivas de triticale (Triticum turgidosecale) $\mathrm{e}$ nabiça (Raphanus raphanistrum) em função da população e proporção de plantas. Planta Daninha. 29(1):129-135, 2011. 